\title{
Dopamine Synthesis Capacity is Associated with D2/3 Receptor Binding but Not Dopamine Release
}

\author{
Anne S Berry, I,2, Vyoma D Shah ${ }^{1,2}$, Daniella J Furman'2, Robert L White III', Suzanne L Baker', \\ James P O'Neil', Mustafa Janabi ', Mark D'Esposito ${ }^{2}$ and William J Jagust ${ }^{\text {I,2 }}$ \\ 'Lawrence Berkeley National Laboratory, Berkeley, CA, USA; ${ }^{2}$ Helen Wills Neuroscience Institute, University of California Berkeley, \\ Berkeley, CA USA
}

\begin{abstract}
Positron Emission Tomography (PET) imaging allows the estimation of multiple aspects of dopamine function including dopamine synthesis capacity, dopamine release, and D2/3 receptor binding. Though dopaminergic dysregulation characterizes a number of neuropsychiatric disorders including schizophrenia and addiction, there has been relatively little investigation into the nature of relationships across dopamine markers within healthy individuals. Here we used PET imaging in 40 healthy adults to compare, within individuals, the estimates of dopamine synthesis capacity $\left(\mathrm{K}_{\mathrm{i}}\right)$ using 6-[ $\left.{ }^{[8} \mathrm{F}\right]$ fluoro-l-m-tyrosine $\left(\left[{ }^{18} \mathrm{~F}\right] \mathrm{FMT}\right.$; a substrate for aromatic amino acid decarboxylase), baseline D2/3 receptor-binding potential using [ ' 'C]raclopride (a weak competitive D2/3 receptor antagonist), and dopamine release using [ ' $\mathrm{C}$ ] raclopride paired with oral methylphenidate administration. Methylphenidate increases synaptic dopamine by blocking the dopamine transporter. We estimated dopamine release by contrasting baseline D2/3 receptor binding and D2/3 receptor binding following methylphenidate. Analysis of relationships among the three measurements within striatal regions of interest revealed a positive correlation between $\left[{ }^{18} \mathrm{~F} F M T \mathrm{~K}_{\mathrm{i}}\right.$ and the baseline (placebo) $\left[{ }^{1} \mathrm{C}\right]$ raclopride measure, such that participants with greater synthesis capacity showed higher D2/3 receptor-binding potential. In contrast, there was no relationship between $\left[{ }^{18} \mathrm{~F}\right] \mathrm{FMT}$ and methylphenidate-induced $\left[{ }^{1} \mathrm{C}\right]$ raclopride displacement. These findings shed light on the nature of regulation between pre- and postsynaptic dopamine function in healthy adults, which may serve as a template from which to identify and describe alteration with disease.

Neuropsychopharmacology (2018) 43, I201-1211; doi:10.1038/npp.2017.180; published online 4 October 2017
\end{abstract}

\section{INTRODUCTION}

In humans, in vivo PET imaging can be used to assess the function of multiple components of the dopamine system by targeting presynaptic markers of synthesis and transport, and postsynaptic markers of receptor-binding potential.

Given the highly regulated nature of the dopamine system, it is possible that pre- and postsynaptic function is dynamically adjusted to achieve a stable homeostatic balance in healthy adults. However, the nature of these relationships is not well understood, as multiple components of the dopamine system are rarely studied within the same individuals (though see Lee et al, 2000; Nandhagopal et al, 2009; Nandhagopal et al, 2011 for examples of multi-tracer studies of presynaptic function in Parkinson's disease; and Ito et al, 2017 for example in healthy adults). In this study, we aimed to characterize the relationship between dopamine synthesis capacity using the PET radioligand $6-\left[{ }^{18} \mathrm{~F}\right]$ fluoro-l-m-tyrosine $\left(\left[{ }^{18} \mathrm{~F}\right] \mathrm{FMT}\right)$, baseline D2/3 receptor-binding potential using $\left[{ }^{11} \mathrm{C}\right]$ raclopride, and dopamine release using methylphenidate-paired $\left[{ }^{11} \mathrm{C}\right]$ raclopride PET in healthy adults.

\footnotetext{
*Correspondence: Dr A Berry, Helen Wills Neuroscience Institute, University of California Berkeley, I 32 Barker Hall, Berkeley, CA 94720, USA, Tel: +(5 I0) 643-6616, E-mail: aberry@lbl.gov

Received 22 March 2017; revised 7 August 2017; accepted 10 August 2017; accepted article preview online 17 August 2017
}

There has been little rigorous investigation into the association between PET markers of dopamine synthesis and receptor binding, though previous studies have begun to address this question with inconsistent results. A single study reported a negative relationship between dopamine synthesis capacity measured using $\left[\beta{ }^{11} \mathrm{C}\right]$ dihydroxyphenylalanine (DOPA) and baseline D2/3 receptor binding measured using $\left[{ }^{11} \mathrm{C}\right]$ raclopride (Ito et al, 2011), and two studies have reported no relationship between dopamine synthesis capacity measured using $\left[{ }^{18} \mathrm{~F}\right]$ DOPA and baseline D2/3 receptor binding measured using $\left[{ }^{18} \mathrm{~F}\right]$ desmethoxyfallypride (Heinz et al, 2005; Kienast et al, 2008). This study design represents a departure from these previous investigations by (1) using a substantially larger sample size ( $n=40$ compared to $n=12-14)$ (2) measuring dopamine synthesis capacity using $\left[{ }^{18} \mathrm{~F}\right] \mathrm{FMT}$, which has an improved signal to noise ratio relative to $\left[{ }^{11} \mathrm{C}\right.$ and $\left.{ }^{18} \mathrm{~F}\right] \mathrm{DOPA}$ ligands (Sossi et al, 2002) and (3) relating dopamine synthesis capacity to dopamine release in addition to baseline D2/3 receptor-binding potential, where signal is influenced both by the density and avidity of receptors as well as by the concentration of synaptic dopamine.

To measure individual differences in dopamine release, we compared baseline $\left[{ }^{11} \mathrm{C}\right]$ raclopride signal (non-displaceable binding potential $\left.\left(\mathrm{BP}_{\mathrm{ND}}\right)\right)$ with $\left[{ }^{11} \mathrm{C}\right]$ raclopride $\mathrm{BP}_{\mathrm{ND}}$ following methylphenidate administration. There is a rich history of research establishing effects of pharmacological 
challenge on PET and SPECT measures of the dopamine system. For example, early studies established that treatment with amphetamine, which stimulates dopamine release (Kuczenski and Segal, 1989; Sharp et al, 1987), also reduces radioligand signal for tracers that bind to dopamine receptors (Breier et al, 1997; Kohler et al, 1981; Laruelle et al, 1996; Laruelle et al, 1995; Laruelle et al, 1997; Martinez et al, 2003; Ross and Jackson, 1989a; Ross et al, 1989b; Young et al, 1991). Released dopamine accumulates in the synapse and competes with the radioligand for postsynaptic receptor binding, thus causing reduction in signal following amphetamine treatment. Methods for estimating in vivo changes in extracellular dopamine concentration using PET and SPECT imaging methods have been validated in elegant studies pairing microdialysis and imaging in nonhuman primates following amphetamine exposure (Breier et al, 1997; Endres et al, 1997; Laruelle et al, 1997; Narendran et al, 2014; Tsukada et al, 1999). These studies confirmed negative correlations between measured increases in extracellular dopamine concentration and reduced radioligand binding.

Building from findings using amphetamine, studies pairing methylphenidate administration with $\left[{ }^{11} \mathrm{C}\right]$ raclopride have established effects of unstimulated, endogenous dopamine release on D2/3 receptor binding. Methylphenidate does not stimulate dopamine release, but increases synaptic concentrations of dopamine by reducing dopamine reuptake via dopamine transporter blockade (Kuczenski and Segal, 1997; Volkow et al, 1998b). In a series of studies in humans, Volkow et al (1999) demonstrated that intravenous and oral methylphenidate (Volkow et al, 2001; Volkow et al, 2002) significantly reduced $\left[{ }^{11} \mathrm{C}\right]$ raclopride $\mathrm{BP}_{\mathrm{ND}}$ in striatum, consistent with findings for amphetamine-stimulated release. Next, Volkow et al (2002) examined whether individual differences in the extent of methylphendiate's blockade of the dopamine transporter explained observed variability in the magnitude of $\left[{ }^{11} \mathrm{C}\right]$ raclopride signal reduction. Change in dopamine transporter binding following oral methylphenidate was measured with $\left[{ }^{1 \mathrm{l}} \mathrm{C}\right]$ cocaine and compared to change in $\left[{ }^{11} \mathrm{C}\right]$ raclopride binding. There was no significant relationship between these measures, which has been interpreted to indicate that individual differences in $\left[{ }^{11} \mathrm{C}\right]$ raclopride binding arise from differences in the activity of dopamine-releasing neurons rather than differences in transporter blockade. Therefore, individuals with low dopaminergic neuronal activity would have smaller increases in synaptic dopamine concentrations relative to individuals with high activity. To date, it is not known whether higher dopamine cell activity and release are associated with increased dopamine synthesis capacity.

This study comprehensively compared measures of $\left[{ }^{18} \mathrm{~F}\right]$ FMT $\mathrm{K}_{\mathrm{i}}$, baseline $\left[{ }^{11} \mathrm{C}\right]$ raclopride $\mathrm{BP}_{\mathrm{ND}}$, and dopamine release within subjects with the aim of addressing the fundamental question of how pre- and postsynaptic components of the dopamine system are interrelated. This study significantly advances efforts in the field to understand basic dopaminergic function in humans by empirically testing multi-tracer relationships that have not, to our knowledge, been investigated previously. We hypothesized that higher levels of dopamine release, putatively reflecting higher dopaminergic neuronal activity, would positively predict individual differences in dopamine synthesis capacity in healthy young participants. We did not have a strong hypothesis regarding the nature of relationships between dopamine synthesis capacity and baseline D2/3 receptor binding given the mixed evidence to date (Heinz et al, 2005; Ito et al, 2011; Kienast et al, 2008).

\section{MATERIALS AND METHODS}

\section{Participants}

40 participants $(18-25$ years old, Mean $=21.33, \mathrm{SD}=1.99$; men/women $=15 / 25 ; 23$ Asian, 7 Hispanic or Latino, 6 White (not Hispanic or Latino), 2 Black or AfricanAmerican, 2 more than one race) underwent PET and MRI scanning. Power analyses determined that this sample size is sufficient to detect relationships of $r=0.32$ with achieved power of 0.80 . Power analyses were conducted with $\mathrm{G}^{\star}$ Power 3.1.7 (Faul et al, 2007). The Institutional Review Boards at the University of California, Berkeley and Lawrence Berkeley National Laboratory approved the study. All participants provided written consent and received monetary compensation for participating in the study.

Participants were recruited as part of a larger ongoing study of dopaminergic mechanisms of cognitive control, which included three fMRI sessions, and self-report questionnaires. Analysis of fMRI results, and self-report measures is ongoing, and is not presented in the current report. Prior to enrollment, participants underwent medical screening and physical examination by a medical doctor or nurse practitioner. Participants did not have a history of neurological, psychological, or psychiatric disorder. Four participants reported having seen a psychiatrist or psychologist to treat school or family stress that was resolved at the time of enrollment, and did not require pharmacological treatment. Participants reported no symptoms of depression, anxiety, paranoia or hallucinations, homicidal thoughts or acts, violent or threatening behavior, suicidal thoughts or acts, or suicide attempts. Self-report measures were collected through paper and pencil questionnaires.

Exclusion criteria included consumption of more than 7 alcoholic drinks per week, and use of psychoactive drugs within 2 weeks of enrollment or 10 times in the past year. We assessed drug history using a written screening form. Participants indicated their drug use history for the following list of specific drugs as well as broader drug categories: cocaine, stimulants (other than caffeine), amphetamines, hallucinogens, 'ecstasy', opiates, sedatives, pain or sleeping pills, and marijuana. In addition, we tested drug and alcohol use via urine drug screening and alcohol breath test prior to enrollment. No participant tested positive for any psychoactive drug, and alcohol breath test confirmed alcohol concentration below $0.05 \%$. Prior to the PET and MRI sessions, participants underwent additional screening for self-reported drug use including screening for methylphenidate, dexmethylphenidate, dextroamphetamine, lisdexamfetamine, amphetamine and methamphetamine. Reported medications were limited to birth control, antibiotics, asthma and allergy medication, and non-prescription pain relievers. Participants did not use nicotine with the exception of two participants who reported smoking 1-2 cigarettes per week. Exclusion of these two participants does not change the significance of our analyses (data not shown). 


\section{Structural MRI Scan}

Images were acquired using a Siemens $3 \mathrm{~T}$ Trio Tim scanner with a 12-channel coil. Each participant was scanned 3 times using a high-resolution T1-weighted magnetization prepared rapid gradient echo (MPRAGE) whole brain scan $\left(\mathrm{TR}=2,300 \mathrm{~ms} ; \mathrm{TE}=2.98 \mathrm{~ms} ; \quad \mathrm{FA}=9^{\circ} ; \quad\right.$ matrix $=240 \times 256$; FOV = 256; sagittal plane; voxel size $=1 \times 1 \times 1 \mathrm{~mm}$; 160 slices). MPRAGE scans were aligned, averaged and segmented using FreeSurfer version 5.1 (http://surfer.nmr.mgh.harvard.edu/) and were used for coregistration with the PET data. The 3 MPRAGE scans were averaged to minimize the effect of head motion on the quality of image segmentation.

\section{$\left[{ }^{18}\right.$ F]FMT PET Data Acquisition}

Participants underwent an $\left[{ }^{18} \mathrm{~F}\right] \mathrm{FMT}$ PET scan to measure dopamine synthesis capacity. $\left[{ }^{18} \mathrm{~F}\right] \mathrm{FMT}$ is similar to DOPA ligands as both tracers are substrates for aromatic amino acid decarboxylase, an enzyme in the dopamine synthesis pathway. Though not the rate-limiting step, its activity provides an estimate of dopamine synthesis capacity when provided with enough substrate (DeJesus, 2003). [ $\left.{ }^{18} \mathrm{~F}\right] \mathrm{FMT}$ does not undergo post-release processing as DOPA ligands do, but is instead trapped in the presynaptic terminal after its conversion to 6$\left[{ }^{18} \mathrm{~F}\right]$ fluorohydroxyphenylacetic acid (Jordan et al, 1997). Furthermore, it is not subject to methylation by catechol-Omethyltransferase as DOPA ligands are, with the consequence that radiolabeled metabolites do not enter the brain. Both of these factors result in improved signal to noise ratio in $\left[{ }^{18} \mathrm{~F}\right]$ FMT images compared to DOPA ligands.

$\left[{ }^{18}\right.$ F]FMT was synthesized at Lawrence Berkeley National Laboratory using methods previously described (VanBrocklin et al, 2004). Participants ingested $2.5 \mathrm{mg} / \mathrm{kg}$ of carbidopa $\sim 1 \mathrm{~h}$ before scanning to minimize the peripheral decarboxylation of $\left[{ }^{18} \mathrm{~F}\right] \mathrm{FMT}$ (Boyes et al, 1986; Firnau et al, 1988; Hoffman et al, 1992; Melega et al, 1990). All PET data were acquired using a Siemens Biograph Truepoint 6 PET/CT scanner (Siemens Medical Systems, Erlangen, Germany). After a short CT scan, participants were injected with approximately $2.5 \mathrm{mCi}$ of $\left[{ }^{18} \mathrm{~F}\right] \mathrm{FMT}$ as a bolus in an antecubital vein $(\mathrm{M} \pm \mathrm{SD}$; specific activity $=$ $947.30 \pm 140.26 \mathrm{mCi} / \mathrm{mmol}$; dose $=2.43 \pm 0.06 \mathrm{mCi})$. Dynamic acquisition frames were obtained over $90 \mathrm{~min}$ in $3 \mathrm{D}$ mode ( 25 frames total: $5 \times 1,3 \times 2,3 \times 3,14 \times 5 \mathrm{~min}$ ). Data were reconstructed using an ordered subset expectation maximization algorithm with weighted attenuation, corrected for scatter, and smoothed with a $4 \mathrm{~mm}$ full width at half maximum (FWHM) kernel.

\section{$\left[{ }^{11} \mathrm{C}\right]$ raclopride PET Data Acquisition}

Participants received two $\left[{ }^{11} \mathrm{C}\right]$ raclopride PET scans an average of 21.65 days before or after the $\left[{ }^{18} \mathrm{~F}\right]$ FMT scan (median $=7$ days) to measure $\mathrm{D} 2 / 3$ receptor occupancy and dopamine release. $\left[{ }^{11} \mathrm{C}\right]$ raclopride is a $\mathrm{D} 2 / 3$ receptor antagonist with relatively low affinity $(\mathrm{Kd}=1.2 \mathrm{nM})$ that competes with endogenous dopamine (Kohler et al, 1985; Seeman et al, 1989). [ $\left.{ }^{11} \mathrm{C}\right]$ raclopride was synthesized at Lawrence Berkeley National Laboratory using methods previously described (Volkow et al, 1993). To measure baseline D2/3 receptor occupancy, participants ingested a placebo pill approximately $1 \mathrm{~h}$ before $\left[{ }^{11} \mathrm{C}\right]$ raclopride scan 1 . The placebo scan was always performed first. To measure dopamine release, participants ingested $30 \mathrm{mg}(\mathrm{M} \pm \mathrm{SD}$ $\mathrm{mg} / \mathrm{kg}: 0.46 \pm 0.08)$ of methylphenidate $\sim 1 \mathrm{~h}$ before $\left[{ }^{11} \mathrm{C}\right]$ raclopride scan 2. Endogenous dopamine release was measured as the percent change in $\mathrm{BP}_{\mathrm{ND}}$ from $\left[{ }^{11} \mathrm{C}\right]$ raclopride scan 1 to $\left[{ }^{11} \mathrm{C}\right.$ ) raclopride scan 2 ((placebo $\left[{ }^{11} \mathrm{C}\right]$ raclopride methylphenidate $\left[{ }^{11} \mathrm{C}\right]$ raclopride)/placebo $\left[{ }^{11} \mathrm{C}\right]$ raclopride). Scans were conducted on the same day, $2 \mathrm{~h}$ apart and participants were blind to whether placebo or methylphenidate was administered. The $30 \mathrm{mg}$ pill provides a smaller dose than the $60 \mathrm{mg}$ pill used in previous studies (Broft et al, 2012; Clatworthy et al, 2009; Martinez et al, 2011; Martinez et al, 2012; Volkow et al, 2001; Volkow et al, 2002). The fixed mg amount used here and by others has the disadvantage of not accounting for individual differences in body weight. Our pilot testing determined the $30 \mathrm{mg}$ pill produced a percent reduction in $\left[{ }^{11} \mathrm{C}\right]$ raclopride signal within the range of signal reduction in $\left[{ }^{11} \mathrm{C}\right]$ raclopride $\mathrm{BP}_{\mathrm{ND}}$ associated with cognitive task performance: $5.3-10.2 \%$ (Jonasson et al, 2014; Monchi et al, 2006). For both $\left[{ }^{11} \mathrm{C}\right]$ raclopride scan 1 and $\left[{ }^{11} \mathrm{C}\right]$ raclopride scan 2, after a short CT scan, participants were injected with approximately $10 \mathrm{mCi}$ of $\left[{ }^{11} \mathrm{C}\right]$ raclopride as a bolus in an antecubital vein. Mean specific activity and dose were not significantly different for $\left[{ }^{11} \mathrm{C}\right]$ raclopride scan 1 $(\mathrm{M} \pm \mathrm{SD}$; specific activity $=5280.45 \pm 1359.41 \mathrm{Ci} / \mathrm{mmol}$, dose $=9.83 \pm 0.07 \mathrm{mCi}$ ) and $\left[{ }^{11} \mathrm{C}\right]$ raclopride scan 2 (specific activity $=5092.98 \pm 1533.82 \mathrm{Ci} / \mathrm{mmol}$, dose $=9.83 \pm 0.09 \mathrm{mCi})$ as assessed by paired $t$-tests (specific activity $t(39)=1.08$, $p=0.29, \mathrm{dz}=0.17$; dose $t(39)=0.27, p=0.79, \mathrm{dz}=0.00)$. Dynamic acquisition frames were obtained over $60 \mathrm{~min}$ in 3D mode (19 frames total: $5 \times 1,3 \times 2,3 \times 3,8 \times 5$ ). Reconstruction was performed as described above.

\section{PET Data Analysis}

PET data were preprocessed using SPM8 software (Friston et al, 2007). To correct for motion between frames, images were realigned to the middle frame. The first five images were summed prior to realignment to improve realignment accuracy, as these early images have relatively low signal contrast. Structural images were coregistered to PET images using the mean image of frames corresponding to the first $20 \mathrm{~min}$ of acquisition as a target. The mean image for the first 20 min was used rather than the mean image for the whole scan time because it provides a greater range in image contrast outside of striatum thus making it a better target for coregistration.

For $\left[{ }^{18} \mathrm{~F}\right] \mathrm{FMT}$ PET, graphical analysis for irreversible tracer binding was performed using Patlak plotting (Patlak and Blasberg, 1985; Sossi et al, 2003) implemented using inhouse software and Matlab version 8.2 (The MathWorks, Natick, MA). Without measurement of the arterial input function, both $\left[{ }^{18} \mathrm{~F}\right] \mathrm{FMT}$ and $\left[{ }^{11} \mathrm{C}\right]$ raclopride PET analysis used reference region models. Such analyses rely on the existence of a tissue region with few specific binding sites (Blomqvist et al, 1989; Cunningham et al, 1991). Cerebellar gray matter was used as the reference region because this region shows very little tracer uptake, and has an extremely low density of dopamine receptors and metabolites relative to striatum (Camps et al, 1989; Farde et al, 1986; Hall et al, 1994; Levey et al, 1993). The most anterior $1 / 4$ of cerebellar 
gray was removed from the reference region to limit contamination of signal from the substantia nigra and ventral tegmental area. Exclusion of the anterior portion of the cerebellar gray has been reported previously (Aarts et al, 2014; Berry et al, 2016; Braskie et al, 2011; Braskie et al, 2008; Dang et al, 2017; Dang et al, 2012a; Dang et al, 2012b, 2013; Dang et al, 2016; Klostermann et al, 2012; Smith et al, 2016; Wallace et al, 2014), and was performed by manually removing the anterior $1 / 4$ of coronal slices from individual participants' native space cerebellar gray FreeSurfer segmentation using Mango software (http://ric.uthscsa.edu/mango/). $\mathrm{K}_{\mathrm{i}}$ images were generated from PET frames corresponding to 25 to $90 \mathrm{~min}$ (Ito et al, 2006; Ito et al, 2007), which represent the amount of tracer accumulated in the brain relative to the reference region. $\mathrm{K}_{\mathrm{i}}$ can be expressed as $K_{\mathrm{i}}=k_{2} k_{3} /\left(k_{2}+k_{3}\right)$, where $k_{2}$ is the rate constant for the return of free $\left[{ }^{18} \mathrm{~F}\right] \mathrm{FMT}$ from brain back to plasma and $k_{3}$ is the rate constant for the trapping of brain $\left[{ }^{18} \mathrm{~F}\right] \mathrm{FMT}$ by aromatic amino acid decarboxylase. These images are comparable to $K_{\mathrm{i}}$ images obtained using a blood input function but are scaled to the volume of tracer distribution in the reference region (Figure 1a).

For $\left[{ }^{11} \mathrm{C}\right]$ raclopride PET, reversible tracer binding was quantified using simplified reference tissue model analysis (SRTM; Lammertsma and Hume, 1996). Specifically, a basis function version of the SRTM was applied as previously described (Gunn et al, 1997) with posterior cerebellar gray matter used as the reference region. Using this method, the time-activity curve of the brain region of interest is described relative to the reference region. This analysis assumes the reference region has no specific binding and that both regions have the same level of nondisplaceable binding (Gunn et al, 1997; Lammertsma and Hume, 1996; Salinas et al, 2015). The SRTM analysis was performed using inhouse software provided by Dr Roger Gunn and Matlab version 8.2. SRTM analysis was used to determine $\mathrm{BP}_{\mathrm{ND}}$, which can be defined as:

$$
\mathrm{BP}_{\mathrm{ND}}=\mathrm{f}_{\mathrm{ND}} \times \mathrm{B}_{\text {avail }} / \mathrm{K}_{\mathrm{D}}
$$

where $B_{\text {avail }}$ is the concentration of $\mathrm{D} 2 / 3$ receptors, $K_{\mathrm{D}}$ is the inverse of the affinity of the radiotracer for $D 2 / 3$ receptors, and $\mathrm{f}_{\mathrm{ND}}$ is the free fraction of the ligand in the nondisplaceable tissue compartment (Innis et al, 2007;
Slifstein and Laruelle, 2001). A $\mathrm{BP}_{\mathrm{ND}}$ voxel-wise map was generated for each participant (Figures $1 \mathrm{~b}$ and $\mathrm{c}$ ).

The use of $\mathrm{BP}_{\mathrm{ND}}$ relies on the assumption that nondispaceable binding is independent of treatment effects. Methylphenidate administration has been shown not to alter cerebellar $\left[{ }^{11} \mathrm{C}\right]$ raclopride signal following $60 \mathrm{mg}$ oral administration (Volkow et al, 2001; Volkow et al, 2002). It is possible that intravenous methylphenidate administration reduces cerebellar distribution volume (Volkow et al, 2014), though these results are not consistent (Volkow et al, 1999). Without measurement of the arterial input function, we could not directly test the effect of $30 \mathrm{mg}$ oral administration cerebellar $\mathrm{BP}$. We did, however, confirm that the cerebellar region of interest (ROI) did not show significant changes in $\mathrm{BP}_{\mathrm{ND}}$ between $\left[{ }^{11} \mathrm{C}\right]$ raclopride scans 1 and 2 when using occipital cortex as the reference region $(t(39)=0.70, p=0.49, \mathrm{dz}=$ 0.11 ). Occipital cortex also did not show significant changes in $\mathrm{BP}_{\mathrm{ND}}$ between $\left[{ }^{11} \mathrm{C}\right]$ raclopride scans 1 and 2 when posterior cerebellar gray was used as the reference region $(t(39)=0.47, p=0.64, \mathrm{dz}=0.07)$.

\section{Regions of Interest}

An ROI approach was used to test relationships between $\left[{ }^{18} \mathrm{~F}\right]$ FMT $\mathrm{K}_{\mathrm{i}}$, baseline $\left[{ }^{11} \mathrm{C}\right]$ raclopride $\mathrm{BP}_{\mathrm{ND}}$, and percent change in $\left[{ }^{11} \mathrm{C}\right]$ raclopride $\mathrm{BP}_{\mathrm{ND}}$ (dopamine release). ROI analyses were conducted in two ways. First, a single striatal ROI mask (henceforth referred to as 'whole striatum') was generated from group level voxel-wise analyses of $\mathrm{K}_{\mathrm{i}}$ and $\mathrm{BP}_{\mathrm{ND}}$ maps. $\mathrm{K}_{\mathrm{i}}$ and $\mathrm{BP}_{\mathrm{ND}}$ maps were spatially normalized to the TPM.nii template in MNI space, and smoothed with a $4 \mathrm{~mm}$ FWHM kernel in SPM 12. Two one-sample t-tests were performed to define significant voxels for $\left[{ }^{18} \mathrm{~F}\right] \mathrm{FMT} \mathrm{K}_{\mathrm{i}}$ and baseline $\left[{ }^{11} \mathrm{C}\right]$ raclopride $\mathrm{BP}_{\mathrm{ND}}$. Paired $t$-test determined voxels for which methylphenidate significantly reduced $\mathrm{BP}_{\mathrm{ND}}$. An initial cluster forming threshold of $p<0.001$ was applied. An additional minimum cluster extent threshold $(k=55, p<0.05)$ was applied using 3dClustSim in AFNI (https://afni.nimh.nih.gov/). The whole striatum mask was comprised of the intersection of voxels $\left(7097 \mathrm{~mm}^{3}\right)$ surviving group level testing for $\left[{ }^{18} \mathrm{~F}\right] \mathrm{FMT} \mathrm{K}_{\mathrm{i}}$ and baseline $\left[{ }^{11} \mathrm{C}\right]$

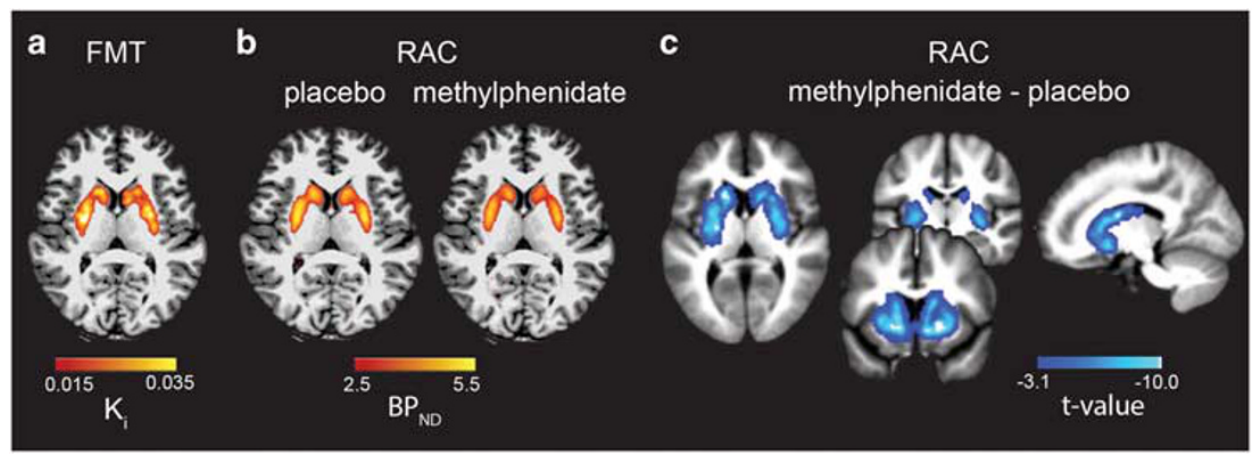

Figure I Within-subject measures of dopamine synthesis capacity and D2/3 receptor binding. (a) $\left[{ }^{18} \mathrm{~F}\right] \mathrm{FMT} \mathrm{K}_{\mathrm{i}}$ signal reflecting dopamine synthesis capacity was measured throughout striatum. The axial slice illustrates the extent of the striatal $K_{i}$ signal for a representative subject overlaid on the subject's native space TI MPRAGE. (b) [ ${ }^{19} \mathrm{C}$ ]raclopride BP ${ }_{\text {ND }}$ displayed for placebo (baseline) scan as well as post-methylphenidate scan for the same representative subject. Methylphenidate administration reduced $\left[{ }^{\prime \prime} \mathrm{C}\right]$ raclopride $B P_{N D}$. (c) Striatal regions showing significantly reduced $\left[{ }^{\prime \prime} C_{r}\right.$ raclopride $B P_{N D}$ following methylphenidate administration across all participants. The t-map for the paired t-test comparing baseline and post-methylphenidate [ $\left.{ }^{1}{ }^{\mathrm{C}}\right]$ raclopride $\mathrm{BP} \mathrm{ND}$ is displayed on the normalized mean TI MPRAGE for all subjects. 
raclopride $\mathrm{BP}_{\mathrm{ND}}$ one-sample $t$-tests, and change in $\left[{ }^{11} \mathrm{C}\right]$ raclopride $\mathrm{BP}_{\mathrm{ND}}$ paired $t$-test $\left(\left[{ }^{18} \mathrm{~F}\right] \mathrm{FMT} \mathrm{K}_{\mathrm{i}} \cap\right.$ baseline $\left[{ }^{11} \mathrm{C}\right]$ raclopride $\mathrm{BP}_{\mathrm{ND}} \cap$ placebo $\left[{ }^{11} \mathrm{C}\right]$ raclopride $\mathrm{BP}_{\mathrm{ND}}>$ methyphenidate $\left[{ }^{11} \mathrm{C}\right]$ raclopride $\left.\mathrm{BP}_{\mathrm{ND}}\right)$.

Secondary, exploratory analyses examined the consistency of relationships between $\left[{ }^{18} \mathrm{~F}\right] \mathrm{FMT} \mathrm{K}_{\mathrm{i}}$ and $\left[{ }^{11} \mathrm{C}\right]$ raclopride $\mathrm{BP}_{\mathrm{ND}}$ measures in striatal subregions. Striatal subregions were manually drawn for each participant. ROIs were drawn in native space on each participant's averaged MPRAGE MRI scan using Mango software. The dorsal caudate, dorsal putamen, and ventral striatum were drawn as previously described (Mawlawi et al, 2001). This manual segmentation protocol was designed to create structurally defined ROIs that reflect the dorsal-ventral functional organization of the striatum. Specifically, ventral aspects of caudate and putamen are included in the ventral striatum ROI along with nucleus accumbens. These ventral portions of caudate and putamen partially surround nucleus accumbens, and share cortical and subcortical inputs from the limbic system (Haber et al, 1994; Poletti and Creswell, 1977; Russchen et al, 1985; Van Hoesen et al, 1981; Yeterian and Van Hoesen, 1978). Inter-rater reliability was high for manually drawn striatal subregions. For ROIs of five participants drawn by 3 raters, the Sorensen-Dice coefficient ranged from 0.80 to 0.89 , and the intra-class correlation coefficient ranged from 0.87 to 0.99 for PET $\left[{ }^{18} \mathrm{~F}\right] \mathrm{FMT} \mathrm{K}_{\mathrm{i}}$ signal extracted from ROIs. Mean \pm SD ROI volumes were $2042 \pm 377 \mathrm{~mm}^{3}$ for dorsal caudate, $3759 \pm 608 \mathrm{~mm}^{3}$ for dorsal putamen, and $1788 \pm 330 \mathrm{~mm}^{3}$ for ventral striatum.

\section{Statistical Analyses}

Statistical analyses were performed using SPSS, version 24. Analyses compared $\left[{ }^{18} \mathrm{~F}\right] \mathrm{FMT}$ and $\left[{ }^{11} \mathrm{C}\right]$ raclopride measures in striatum. Pearson correlations tested relationships between striatal $\left[{ }^{18} \mathrm{~F}\right] \mathrm{FMT} \mathrm{K}_{\mathrm{i}},\left[{ }^{11} \mathrm{C}\right]$ raclopride $\mathrm{BP}_{\mathrm{ND}}$, and dopamine release (\% change: $\left(\left[{ }^{11} \mathrm{C}\right]\right.$ raclopride $\mathrm{BP}_{\mathrm{ND}}$ placebo $-\left[{ }^{11} \mathrm{C}\right]$ raclopride $\mathrm{BP}_{\mathrm{ND}}$ methylphenidate $\left./ /{ }^{11} \mathrm{C}\right]$ raclopride $\mathrm{BP}_{\mathrm{ND}}$ placebo). Primary correlation analyses were performed for whole striatum defined in MNI space. Secondary analyses tested correlations within striatal subregions (dorsal caudate nucleus, dorsal putamen, ventral striatum) as described above.

Shapiro-Wilk tests confirmed distributions were normal for PET signal in all regions with the exception of percent change in $\left[{ }^{11} \mathrm{C}\right]$ raclopride $\mathrm{BP}_{\mathrm{ND}}$ for whole striatum; a Spearman correlation is reported for the analysis of its relationship with $\left[{ }^{18} \mathrm{~F}\right] \mathrm{FMT} \mathrm{K}_{\mathrm{i}}$. Correlations between $\left[{ }^{18} \mathrm{~F}\right]$
FMT and $\left[{ }^{11} \mathrm{C}\right]$ raclopride \% change are corrected for individual differences in body weight. We report $r$ and $p$-values along with $95 \%$ confidence intervals for the $r$-values based on 1000 bootstrap samples ( $r$, (confidence interval), $p$ ).

Complementary analyses demonstrated the limited impact of partial volume effects on our results. For analyses on manually drawn striatal subregions, we confirmed that all correlations described above remained significant after covarying ROI volume. Second, we confirmed that applying ROIbased partial volume correction (PVC; Rousset et al, 1998) to PET data did not affect our main conclusions. These analyses were performed in native space (non-normalized data) and correct for between-subject differences in the inclusion of white matter and CSF in the measured volumes. To apply the PVC in native space, we used FreeSurfer-generated ROIs for gray matter cortical and subcortical regions, white matter, and cerebral spinal fluid with manually drawn striatal ROIs substituting for the automated striatal segmentation. PVC results are reported in Supplementary information.

\section{RESULTS}

\section{Reduction of $\left[{ }^{11} \mathrm{C}\right]$ raclopride $\mathrm{BP}_{\mathrm{ND}}$ Post Methylphenidate}

Overall, $\left[{ }^{11} \mathrm{C}\right]$ raclopride $\mathrm{BP}_{\mathrm{ND}}$ decreased $8.78 \pm 4.23 \%$ postmethylphenidate $(\mathrm{M} \pm \mathrm{SD}$ for whole striatum). The effect of methylphenidate on $\left[{ }^{11} \mathrm{C}\right]$ raclopride $\mathrm{BP}_{\mathrm{ND}}$ is visualized in the voxel-wise paired t-test comparing $\mathrm{BP}_{\mathrm{ND}}$ following placebo vs $\mathrm{BP}_{\mathrm{ND}}$ following methylphenidate (Figure 1c). A single cluster comprised the entire striatum (peak: MNI 18, 16, -6 , $k=7097$ ). The location of the peak in ventral striatum is consistent with previous reports (Drevets et al, 1999). $\left[{ }^{18} \mathrm{~F}\right]$ FMT $\mathrm{K}_{\mathrm{i}},\left[{ }^{11} \mathrm{C}\right]$ raclopride $\mathrm{BP}_{\mathrm{ND}}$, and percent change in $\left[{ }^{11} \mathrm{C}\right]$ raclopride $\mathrm{BP}_{\mathrm{ND}}$ values for whole striatum and striatal subregion ROIs are reported in Table 1. PVC values are reported in Supplementary Table S1.

\section{Relationship Between Striatal $\left[{ }^{18} \mathrm{~F}\right] \mathrm{FMT} \mathrm{K}_{\mathrm{i}}$ and $\left[{ }^{11} \mathrm{C}\right]$ raclopride $\mathrm{BP}_{\mathrm{ND}}$}

Pearson correlations showed significant positive relationships between $\left[{ }^{18} \mathrm{~F}\right] \mathrm{FMT} \mathrm{K}_{\mathrm{i}}$ and baseline $\left[{ }^{11} \mathrm{C}\right]$ raclopride $\mathrm{BP}_{\mathrm{ND}}$ for whole striatum $(r=0.46[0.17,0.70], p=0.003)$. This relationship was generally consistent across striatal subregions, as there were positive correlations in dorsal caudate and ventral striatum, and a relationship in dorsal

Table I PET Signal in Striatal Regions of Interest

\begin{tabular}{|c|c|c|c|c|}
\hline & {$\left[{ }^{18} \mathrm{~F}\right] \mathrm{FMT} \mathrm{K}_{\mathrm{i}}$} & {$\left[{ }^{1} \mathrm{C} C\right] R A C B P_{N D}$} & {$\left[{ }^{\prime \prime} \mathrm{C}\right] \mathrm{RAC} B \mathrm{P}_{\mathrm{ND}}$} & {$\left[{ }^{\prime \prime} \mathrm{C}\right] \mathrm{RAC} \mathrm{BP}_{\mathrm{ND}}$} \\
\hline & & placebo & methylphenidate & $\%$ change \\
\hline whole striatum & $0.015 \pm 0.002$ & $2.19 \pm 0.18$ & $1.99 \pm 0.18$ & $8.78 \pm 4.23$ \\
\hline dorsal caudate & $0.019 \pm 0.002$ & $3.02 \pm 0.27$ & $2.79 \pm 0.27$ & $7.48 \pm 3.78$ \\
\hline dorsal putamen & $0.024 \pm 0.002$ & $3.85 \pm 0.27$ & $3.48 \pm 0.33$ & $9.63 \pm 5.88$ \\
\hline
\end{tabular}

Values reflect mean \pm standard deviation. \% change was calculated as $100 \times\left(\left[{ }^{\prime \prime} \mathrm{C}\right]\right.$ raclopride placebo-[ $\left[{ }^{\prime \prime} \mathrm{C}\right]$ raclopride methylphenidate)/ [ I $\left.\mathrm{C}\right]$ raclopride placebo. $\left[{ }^{\prime \prime} \mathrm{C}\right]$ raclopride is abbreviated as [ ' $\mathrm{C}] \mathrm{RAC}$. degrees of freedom $=39$. 
Whole striatum
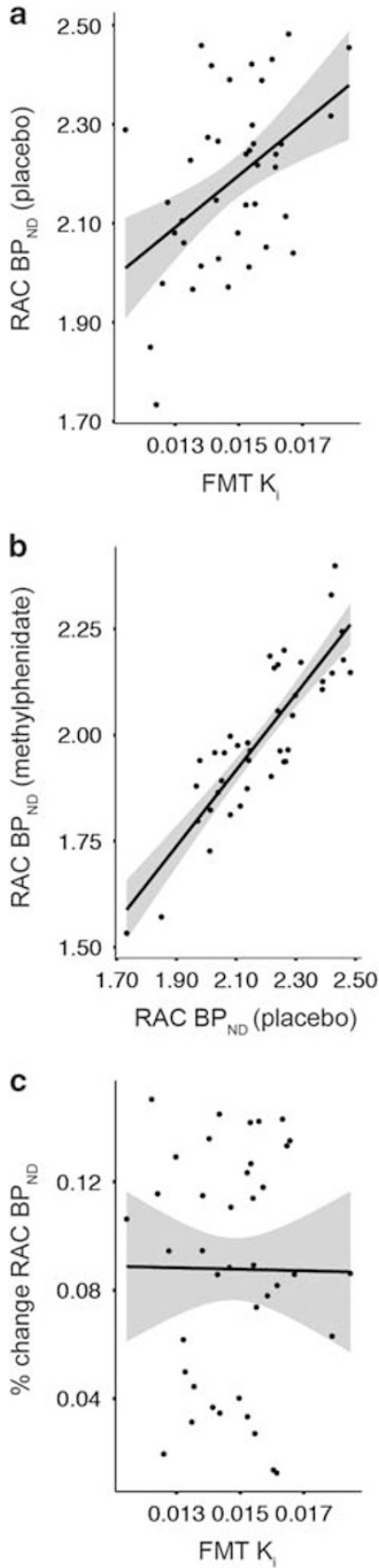

Dorsal caudate
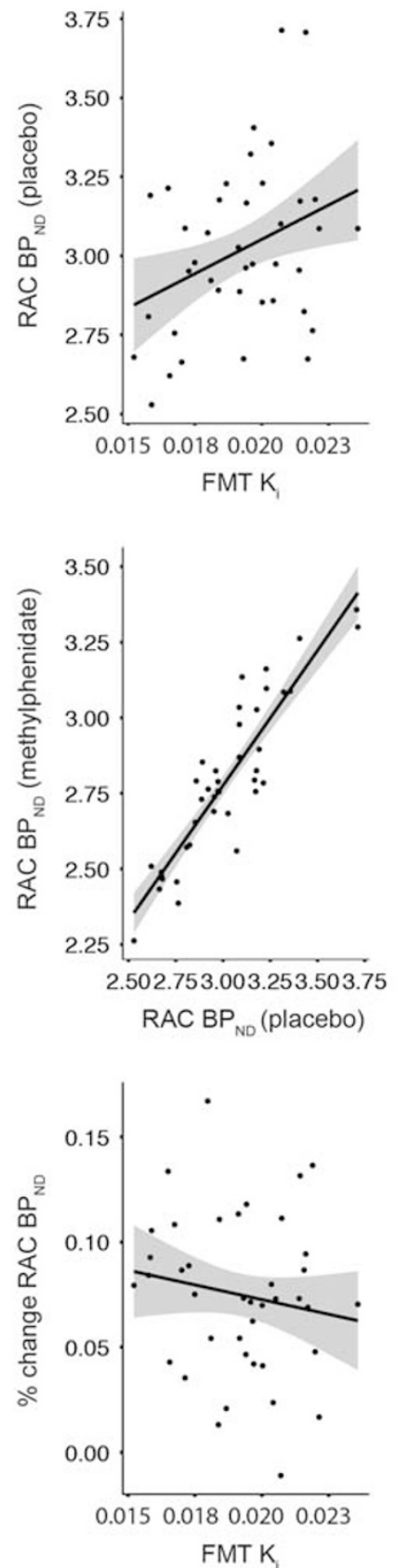

Dorsal putamen

Ventral striatum
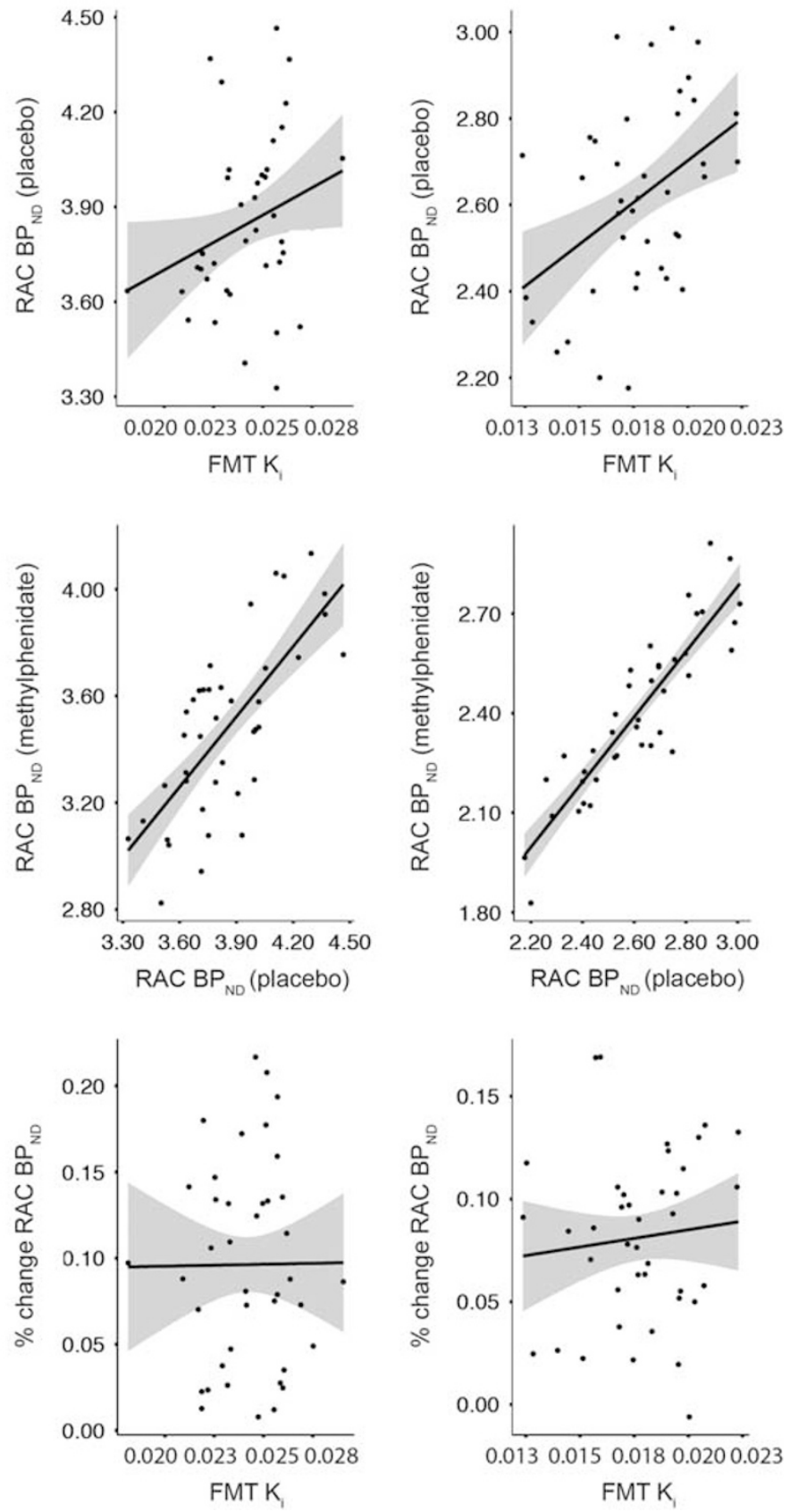

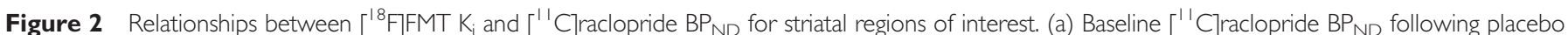
was positively related to $\left[{ }^{18} \mathrm{~F} F M T\right.$ T $K_{i}$ the whole striatum region of interest $(\mathrm{ROI})$ derived from voxel-wise analyses $(r=0.46, p=0.003)$. Baseline $\left[{ }^{11} \mathrm{C}\right]$ raclopride $\mathrm{BP}_{\mathrm{ND}}$ and $\left[{ }^{18} \mathrm{~F}\right.$ FMT $\mathrm{K}_{\mathrm{i}}$ were positively related for manually drawn ROls in dorsal caudate $(r=0.34, p=0.03)$ and ventral striatum $(r=0.4 \mathrm{I}$, $p=0.008)$, and related in dorsal putamen at trend level $(r=0.26, p=0.10)$. (b) [ [ 'C] raclopride BP $\mathrm{ND}$ following methylphenidate and placebo (baseline) were highly correlated $(r=0.72-0.90$, all $p<0.000 \mathrm{I})$. (c) Dopamine release ( $\left(\left[{ }^{1} \mathrm{C} C\right]\right.$ raclopride placebo- $\left[{ }^{11} \mathrm{C}\right]$ raclopride methylphenidate)/ [ $\left.{ }^{1 !} \mathrm{C}\right] \mathrm{raclopride}$ placebo) was not related to $\left[{ }^{18} \mathrm{~F}\right] \mathrm{FMT} \mathrm{K}_{\mathrm{i}}(r=-0.15-0.11$, all $p>0.35)$. [ [ $\left.\mathrm{C}\right]$ raclopride is abbreviated as RAC.

putamen at trend level (Figure 2a; Table 2). Controlling for region volume did not change the reported r-values (data not shown). Further, positive relationships remained following PVC (Supplementary Table S2).

Pearson correlations showed strong positive relationships between baseline $\left[{ }^{11} \mathrm{C}\right]$ raclopride ${ }^{\mathrm{BP}} \mathrm{ND}_{\mathrm{ND}}$ and postmethylphenidate $\left[{ }^{11} \mathrm{C}\right]$ raclopride $\mathrm{BP}_{\mathrm{ND}}$ for the whole striatum ROI $(r=0.86[0.76,0.92], p<0.001)$. Considering striatal subregions independently, there were positive relationships for all ROIs (Figure 2b; Table 2). Controlling for region volume did not change the statistical significance of any relationship, though reduced the $r$-value for ventral striatum by 0.01 (data not shown).

There were no correlations between body weight and individual differences in dopamine release (percent change in $\left[{ }^{11} \mathrm{C}\right]$ raclopride $\mathrm{BP}_{\mathrm{ND}}$ after methylphenidate) in striatal 
Table 2 Correlations between PET measures in striatal regions of interest

\begin{tabular}{|c|c|c|c|}
\hline & {$\left[{ }^{18} \mathrm{~F}\right] \mathrm{FMT}$ vs } & ['C]RAC placebo vs & {$\left[{ }^{18} \mathrm{~F}\right] \mathrm{FMT}$ vs } \\
\hline & ['C]RAC placebo & ['C]RAC methylphenidate & [' 'C]RAC (\% change) \\
\hline dorsal caudate & $r=0.34(0.07,0.57), p=0.031$ & $r=0.90(0.8 \mathrm{I}, 0.95), p<0.00 \mathrm{I}^{\mathrm{a}}$ & $r=-0.15(-0.43,0.15), p=0.352$ \\
\hline dorsal putamen & $r=0.26(-0.05,0.52), p=0.102$ & $r=0.72(0.58,0.82), p<0.00 I^{a}$ & $r=0.01(-0.26,0.28), p=0.936$ \\
\hline
\end{tabular}

R-values (95\% confidence interval) and p-values are reported. Correlations between $\left[{ }^{18} \mathrm{~F}\right] \mathrm{FMT}$ and $\left[{ }^{1} \mathrm{C}\right]$ raclopride \% change: (placebo - methylphenidate)/placebo) are corrected for individual differences in body weight. [ $\left.{ }^{\prime \prime} \mathrm{C}\right]$ raclopride is abbreviated as [ ' $\left.C\right] R A C$. For striatal subregions.

andicates relationships surviving Bonferroni correction for three comparisons.

ROIs for the fixed $30 \mathrm{mg}$ methylphenidate amount (Spearman's $r=0.04-0.11$, all $p>0.49$ ). Spearman correlations were used as Shapiro-Wilks test indicated body weights were not normally distributed $(W=0.91, p=0.004)$.

We did not find a relationship between $\left[{ }^{18} \mathrm{~F}\right] \mathrm{FMT} \mathrm{K}_{\mathrm{i}}$ and dopamine release for whole striatum $(r=-0.01(-0.31,0.33)$, $p=0.97$; for individual ROI results see Figure 2c, Table 2). Controlling for region volume did not change the reported r-values (data not shown). As a further test of the relationship between $\left[{ }^{18} \mathrm{~F}\right] \mathrm{FMT}$ and dopamine release, data from each striatal ROI were submitted to separate multiple regression models with post-methylphenidate $\left[{ }^{11} \mathrm{C}\right]$ raclopride $\mathrm{BP}_{\mathrm{ND}}$ as the dependent variable, and predictors $\left[{ }^{18} \mathrm{~F}\right] \mathrm{FMT} \mathrm{K}_{\mathrm{i}}$, baseline $\left[{ }^{11} \mathrm{C}\right]$ raclopride $\mathrm{BP}_{\mathrm{ND}}$, and region volume. Region volume was not included in the model for the whole striatum ROI, which was defined from normalized group voxel-wise maps and was therefore consistent across subjects. Models for all striatal regions were significant (all $\mathrm{F}(3,36)>13.22$, all $p<5.67 \times 10^{-6}$, adjusted $\left.r^{2}=0.48-0.80\right)$. Baseline $\left[{ }^{11} \mathrm{C}\right]$ raclopride $\mathrm{BP}_{\mathrm{ND}}$ significantly predicted post-methylphenidate $\left[{ }^{11} \mathrm{C}\right]$ raclopride $\mathrm{BP}_{\mathrm{ND}}$ for all models (all $t>5.99, p<7.18 \times 10^{-7}$ ), and $\left[{ }^{18} \mathrm{~F}\right] \mathrm{FMT} \mathrm{K}_{\mathrm{i}}$ did not predict post-methylphenidate $\left[{ }^{11} \mathrm{C}\right]$ raclopride $\mathrm{BP}_{\mathrm{ND}}$ for any model (all $t<0.99, p>0.33$ ).

\section{DISCUSSION}

This study examined relationships between dopamine PET measures of striatal synthesis capacity, baseline striatal D2/3 receptor binding, and striatal dopamine release in a sample of 40 healthy young adults. We found a positive relationship between the presynaptic measure of dopamine synthesis capacity and the postsynaptic measure of baseline D2/3 binding. However, relationships between dopamine synthesis capacity and dopamine release were not evident. Below we describe the major implications of these findings and their caveats.

There are few studies that have investigated the relationships among dopamine PET measures within individuals. To our knowledge, there are only three other studies that have examined the relationship between presynaptic dopamine synthesis capacity and unstimulated D2/3 receptor binding using PET. Though two reported no relationship (Heinz et al, 2005; Kienast et al, 2008), it is possible these studies were underpowered. The Heinz study included 13 healthy controls and 12 alcoholic patients and the Kienast study included 12 healthy controls. Power analyses of the current study's correlation strengths indicated at least 32 subjects were required to measure the relationship between $\left[{ }^{18} \mathrm{~F}\right] \mathrm{FMT}$ $\mathrm{K}_{\mathrm{i}}$ and baseline $\left[{ }^{11} \mathrm{C}\right]$ raclopride $\mathrm{BP}_{\mathrm{ND}}$ in whole striatum with power of 0.80 ( $\mathrm{G}^{*}$ Power; Faul et al, 2007). Ito et al (2011) reported a negative relationship between synthesis capacity (estimated using $\left[{ }^{11} \mathrm{C}\right] \mathrm{DOPA} \mathrm{PET}$ ) and $\mathrm{D} 2 / 3$ receptor binding (estimated using $\left[{ }^{11} \mathrm{C}\right]$ raclopride PET) for the average of signal measured in caudate and putamen. The authors interpreted these findings to suggest either a compensatory relationship between pre- and postsynaptic dopamine function, or the effects of greater synaptic dopamine competing with $\left[{ }^{11} \mathrm{C}\right]$ raclopride for receptor binding in individuals with higher dopamine synthesis. A compensatory response could be mediated by lower D2/3 autoreceptor function, which has been linked to regulation of activity, but not de novo synthesis of aromatic amino acid decarboxylase (Cho et al, 1999; Zhu et al, 1992).

In contrast to the Ito study, we found positive rather than negative relationships between dopamine synthesis capacity and baseline D2/3 receptor binding. Critically, partial volume effects could not account for these correlations. Statistically controlling for ROI volume and formal PVC did not eliminate these positive relationships. The use of $\left[{ }^{18} \mathrm{~F}\right] \mathrm{FMT}$ as opposed to $\left[{ }^{11} \mathrm{C}\right] D O P A$ for estimating dopamine synthesis capacity likely represents the major source of discrepancy between studies. While $\left[{ }^{18} \mathrm{~F}\right] \mathrm{FMT}$ and DOPA ligands both act as substrates for aromatic amino acid decarboxylase, DOPA ligands are subject to additional in vivo metabolism not specific to the dopamine synthesis cascade including transport into vesicles and post-release processing at longer scan times (Sossi et al, 2002). This release and metabolism complicates the interpretation of DOPA ligands' signal, which has been suggested to reflect dopamine turnover rather than synthesis capacity (Dejesus et al, 2001). In contrast, $\left[{ }^{18} \mathrm{~F}\right] \mathrm{FMT}$ is trapped in the presynaptic terminal following its conversion to fluoro-m-hyroxyphenylacetic acid (Jordan et al, 1997). In cases in which both tracers have been measured within subject, the $\left[{ }^{18} \mathrm{~F}\right] \mathrm{DOPA}$ tracer's estimation of turnover rather than synthesis capacity has been implicated in the inversion of relationships observed for $\left[{ }^{18} \mathrm{~F}\right]$ FMT (Dejesus et al, 2001). Therefore, it is possible that the negative relationship between $\left[{ }^{11} \mathrm{C}\right] \mathrm{DOPA}$ and $\mathrm{D} 2 / 3$ receptor binding reported by Ito et al (2011) is driven by poorer estimates of dopamine synthesis capacity, or captures an inverse relationship between dopamine turnover (release and metabolism) and D2/3 receptor binding.

One question to consider is what are the functional and structural drivers underlying the positive relationship we 
observed between dopamine synthesis capacity and D2/3 receptor binding. During development, the number of dopamine-producing neurons innervating the striatum may affect the structural development and arborization of dendrites (McAllister, 2000; Whitford et al, 2002). Hence, the underlying structure (ie, number of synapses and the dendritic branching) may produce positive relationships between pre- and postsynaptic dopamine measures across subjects. Functional studies in animal models indicate that changes in afferent stimulation continue to shape postsynaptic structure (Ingham et al, 1989; Robinson et al, 2001; Robinson and Kolb, 1997; Wang and Deutch, 2008; ZajaMilatovic et al, 2005) and D2 receptor gene expression (Gerfen et al, 1990). Future studies pairing PET imaging and microscopy in animal models may best resolve questions regarding the contribution of the density of dopaminergic inputs to striatum $v s$ their activity (eg individual differences in firing rate) in generating positive relationships between dopamine synthesis capacity and D2/3 receptor binding.

We did not find evidence of a relationship between striatal dopamine synthesis capacity and dopamine release measured with methylphenidate-paired $\left[{ }^{11} \mathrm{C}\right]$ raclopride. Withinsubject relationships between dopamine synthesis and release have not been previously reported. However, one study found both elevated dopamine synthesis capacity and elevated dopamine release in two independent groups of immigrants relative to non-immigrant controls (Egerton et al, 2017). There are many factors that contribute to the rate and volume of neurotransmitter release for which regulation may be independent of aromatic amino acid decarboxylase activity. These factors may have contributed to the lack of correlation between $\left[{ }^{18} \mathrm{~F}\right] \mathrm{FMT} \mathrm{K}_{\mathrm{i}}$ and change in $\left[{ }^{11} \mathrm{C}\right]$ raclopride $\mathrm{BP}_{\mathrm{ND}}$ following methylphenidate. These may include, but are not limited to, the activity of the vesicular monoamine transporter, the activity of vesicular tracking proteins, and the distribution of vesicles in the readily releasable pool. In rodent models, ${ }^{11} \mathrm{C}$ labeling of dopamine precursors suggest that newly synthesized dopamine is not detectable in the synapse, but is stored in synaptic vesicles not immediately released (Okada et al, 2011). These findings suggest some degree of uncoupling between synthesis and release, at least in the time domain.

The methylphenidate-paired $\left[{ }^{11} \mathrm{C}\right]$ raclopride method for measuring dopamine release may be complicated by individual differences in the effect of methylphenidate on dopamine transporters. Volkow et al (1998a, 2002) have used $\left[{ }^{11} \mathrm{C}\right]$ cocaine PET to estimate dopamine transporter binding and displacement after methylphenidate administration. Though there are individual differences in $\left[{ }^{11} \mathrm{C}\right]$ cocaine displacement with methylphenidate, decreases in transporter binding were not correlated with decreases in $\left[{ }^{11} \mathrm{C}\right]$ raclopride binding with methylphenidate (Volkow et al, 2002). The authors concluded that variability in methylphenidate binding to the transporter was not the primary source of individual differences in changes in $\left[{ }^{11} \mathrm{C}\right]$ raclopride $\mathrm{BP}_{\mathrm{ND}}$ with methylphenidate. This, however, does not rule out the possibility that differences in transporter function contribute to estimated dopamine release (see discussion in Volkow et al, 2001). Indeed, there was modest indication of a relationship between baseline $\left[{ }^{11} \mathrm{C}\right]$ cocaine and release measures $(r=0.34)$, though sample size was limited ( $n=10$; Volkow et al, 2002).
It is possible that relationships between dopamine synthesis capacity and dopamine release can be unmasked with alternative pharmacological treatments. The $30 \mathrm{mg}$ methylphenidate pill used here produced average change in $\left[{ }^{11} \mathrm{C}\right]$ raclopride $\mathrm{BP}_{\mathrm{ND}}$ of $8.78 \%$. This is within the $5.3-10.2 \%$ change range described for $\left[{ }^{11} \mathrm{C}\right]$ raclopride $\mathrm{BP}_{\mathrm{ND}}$ observed during cognitive task performance (Jonasson et al, 2014; Monchi et al, 2006). Higher $60 \mathrm{mg}$ oral methylphenidate amounts produce $\left[{ }^{11} \mathrm{C}\right]$ raclopride $\mathrm{BP}_{\mathrm{ND}}$ reductions of approximately 11-20\% (Volkow et al, 2001; Volkow et al, 2002; Martinez et al, 2011; Martinez et al, 2012; Broft et al, 2012). To further probe the null result observed here, future studies should test whether using higher methylphenidate doses or, alternatively, using amphetamine to stimulate dopamine release (Kuczenski and Segal, 1989; Sharp et al, 1987) reveals relationships between $\left[{ }^{18} \mathrm{~F}\right] \mathrm{FMT} \mathrm{K}_{\mathrm{i}}$ and changes in $\left[{ }^{11} \mathrm{C}\right]$ raclopride $\mathrm{BP}_{\mathrm{ND}}$. Additionally, future studies would be strengthened by the use of plasma testing of d-threo methylphenidate (Volkow et al, 1998b) and fixed $\mathrm{mg} / \mathrm{kg}$ doses, the absence of which represent limitations in the present study.

This study sheds light on the unique information conveyed by pre- and post- synaptic measures of dopaminergic function in healthy adults. Though there were positive relationships between $\left[{ }^{18} \mathrm{~F}\right] \mathrm{FMT}$ and baseline $\left[{ }^{11} \mathrm{C}\right]$ raclopride measures, the strength of these correlations were relatively weak $(r=0.26-0.46)$ indicating $\left[{ }^{18} \mathrm{~F}\right] \mathrm{FMT}$ and $\left[{ }^{11} \mathrm{C}\right]$ raclopride cannot simply be used as proxy measures for one another in healthy populations. Considering the limitations of the present study, it is also possible that further screening and stricter exclusion of participants would have strengthened the observed relationships. Specifically, we did not submit participants to urine drug screens on the day of PET scanning, did not include the Structured Clinical Interview for DSM Disorders, and did not exclude for family history of psychiatric disorder, which may affect dopamine synthesis capacity (Huttunen et al, 2008).

This study establishes relationships between pre- and postsynaptic dopamine function in healthy young adults that can be tested in other populations. Alterations in dopamine function are associated with aging, and are a central component of disorders including Parkinson's disease, schizophrenia, and addiction. Evidence for compensatory regulation of dopamine function may be most clear in such populations, where the positive relationships between estimated dopamine synthesis and receptor density observed in healthy adults may disappear with disease or show a reversal in their relationship. For example, in aging, different studies report decreased density of D2/3 receptors (Backman et al, 2000; Kuwabara et al, 2012; Volkow et al, 1998a; Volkow et al, 1996) accompanied by increases in dopamine synthesis capacity (Berry et al, 2016; Braskie et al, 2008).

In summary, our study revealed positive relationships between presynaptic dopamine synthesis capacity and postsynaptic D2/3 receptor binding measures, but failed to provide evidence supporting our hypothesis that dopamine synthesis and release would be positively related. Our results underscore the importance of empirical testing of the interrelationships between dopamine measures, and take initial steps in defining the balance of multiple aspects of the dopamine system in healthy adults. Our findings may offer a template from which to characterize alteration in striatal dopamine function in disease. 


\section{FUNDING AND DISCLOSURE}

This research was generously funded by NIH grants R01 DA034685, R01 AG044292, F32 AG047686, and F32 DA038927. The authors declare no conflict of interest.

\section{ACKNOWLEDGMENTS}

We thank Kaitlin Swinnerton for her work drawing striatal regions of interest.

\section{AUTHOR CONTRIBUTIONS}

WJJ and MD designed the experiments. DJF, RLW, and WJJ collected data. JPO and MJ synthesized the radiotracers. ASB, VDS, and SLB analyzed the data. ASB and WJJ wrote the manuscript with input from all authors.

\section{REFERENCES}

Aarts E, Wallace DL, Dang LC, Jagust WJ, Cools R, D'Esposito M (2014). Dopamine and the cognitive downside of a promised bonus. Psychol Sci 25: 1003-1009.

Backman L, Ginovart N, Dixon RA, Wahlin TB, Wahlin A, Halldin $C$ et al (2000). Age-related cognitive deficits mediated by changes in the striatal dopamine system. Am J Psychiatry 157: 635-637.

Berry AS, Shah VD, Baker SL, Vogel JW, O'Neil JP, Janabi M et al (2016). Aging Affects Dopaminergic Neural Mechanisms of Cognitive Flexibility. J Neurosci 36: 12559-12569.

Blomqvist G, Pauli S, Farde L, Eriksson L, Persson A, Halldin C (1989) Dynamic models of reversible ligand bindingIn:Beckers C, Goffinet A, Bol A (eds). Clinical Research and Clinical Diagnosis. Kluwer Academic Publishers: Dardrecht, The Netherlands. pp 35-44.

Boyes BE, Cumming P, Martin WR, McGeer EG (1986). Determination of plasma [18 F]-6-fluorodopa during positron emission tomography: elimination and metabolism in carbidopa treated subjects. Life Sci 39: 2243-2252.

Braskie MN, Landau SM, Wilcox CE, Taylor SD, O'Neil JP, Baker SL et al (2011). Correlations of striatal dopamine synthesis with default network deactivations during working memory in younger adults. Hum Brain Mapp 32: 947-961.

Braskie MN, Wilcox CE, Landau SM, O'Neil JP, Baker SL, Madison $\mathrm{CM}$ et al (2008). Relationship of striatal dopamine synthesis capacity to age and cognition. J Neurosci 28: 14320-14328.

Breier A, Su TP, Saunders R, Carson RE, Kolachana BS, de Bartolomeis A et al (1997). Schizophrenia is associated with elevated amphetamine-induced synaptic dopamine concentrations: evidence from a novel positron emission tomography method. Proc Natl Acad Sci USA 94: 2569-2574.

Broft A, Shingleton R, Kaufman J, Liu F, Kumar D, Slifstein M et al (2012). Striatal dopamine in bulimia nervosa: a PET imaging study. Int J Eat Disord 45: 648-656.

Camps M, Cortes R, Gueye B, Probst A, Palacios JM (1989). Dopamine receptors in human brain: autoradiographic distribution of D2 sites. Neuroscience 28: 275-290.

Cho S, Duchemin AM, Neff NH, Hadjiconstantinou M (1999). Tyrosine hydroxylase, aromatic L-amino acid decarboxylase and dopamine metabolism after chronic treatment with dopaminergic drugs. Brain Res 830: 237-245.

Clatworthy PL, Lewis SJ, Brichard L, Hong YT, Izquierdo D, Clark L et al (2009). Dopamine release in dissociable striatal subregions predicts the different effects of oral methylphenidate on reversal learning and spatial working memory. J Neurosci 29: 4690-4696. Cunningham VJ, Hume SP, Price GR, Ahier RG, Cremer JE, Jones AK (1991). Compartmental analysis of diprenorphine binding to opiate receptors in the rat in vivo and its comparison with equilibrium data in vitro. J Cereb Blood Flow Metab 11: 1-9.

Dang LC, Castrellon JJ, Perkins SF, Le NT, Cowan RL, Zald DH et al (2017). Reduced effects of age on dopamine D2 receptor levels in physically active adults. NeuroImage 148: 123-129.

Dang LC, Donde A, Madison C, O'Neil JP, Jagust WJ (2012a). Striatal dopamine influences the default mode network to affect shifting between object features. J Cogn Neurosci 24: 1960-1970.

Dang LC, O'Neil JP, Jagust WJ (2012b). Dopamine supports coupling of attention-related networks. J Neurosci 32: 9582-9587.

Dang LC, O'Neil JP, Jagust WJ (2013). Genetic effects on behavior are mediated by neurotransmitters and large-scale neural networks. NeuroImage 66: 203-214.

Dang LC, Samanez-Larkin GR, Castrellon JJ, Perkins SF, Cowan RL, Zald DH (2016). Associations between dopamine D2 receptor availability and BMI depend on age. NeuroImage 138: 176-183.

DeJesus OT (2003). Positron-labeled DOPA analogs to image dopamine terminals. Drug Development Research 59: 249-260.

Dejesus OT, Endres CJ, Shelton SE, Nickles RJ, Holden JE (2001). Noninvasive assessment of aromatic L-amino acid decarboxylase activity in aging rhesus monkey brain in vivo. Synapse 39: 58-63.

Drevets WC, Price JC, Kupfer DJ, Kinahan PE, Lopresti B, Holt D et al (1999). PET measures of amphetamine-induced dopamine release in ventral versus dorsal striatum. Neuropsychopharmacology 21: 694-709.

Egerton A, Howes OD, Houle S, McKenzie K, Valmaggia LR, Bagby MR et al (2017). Elevated striatal dopamine function in immigrants and their children: a risk mechanism for psychosis. Schizophr Bull 43: 293-301.

Endres CJ, Kolachana BS, Saunders RC, Su T, Weinberger D, Breier A et al (1997). Kinetic modeling of [11C] raclopride: combined PET-microdialysis studies. J Cereb Blood Flow Metab 17: 932-942.

Farde L, Hall H, Ehrin E, Sedvall G (1986). Quantitative analysis of D2 dopamine receptor binding in the living human brain by PET. Science 231: 258-261.

Faul F, Erdfelder E, Lang AG, Buchner A (2007). G*Power 3: a flexible statistical power analysis program for the social, behavioral, and biomedical sciences. Behav Res Methods 39: 175-191.

Firnau G, Sood S, Chirakal R, Nahmias C, Garnett ES (1988). Metabolites of 6-[18 F]fluoro-L-dopa in human blood. J Nucl Med 29: 363-369.

Friston KJ, Ashburner JT, Kiebel SJ, Nichols TE, Penny WD (2007). Parametric Mapping: The Analysis of Functional Brain Images. Academic: Amsterdam.

Gerfen CR, Engber TM, Mahan LC, Susel Z, Chase TN, Monsma FJ Jr et al (1990). D1 and D2 dopamine receptor-regulated gene expression of striatonigral and striatopallidal neurons. Science 250: 1429-1432.

Gunn RN, Lammertsma AA, Hume SP, Cunningham VJ (1997). Parametric imaging of ligand-receptor binding in PET using a simplified reference region model. NeuroImage 6: 279-287.

Haber SN, Lynd-Balta E, Spooren WPTM (1994). Integrative aspects of basal gangial circuitry. In: Percheron G, McKenzie JS, Feger J(eds) The Basal Ganglia IV. Plenum Press: New York. pp 71-80.

Hall H, Sedvall G, Magnusson O, Kopp J, Halldin C, Farde L (1994). Distribution of D1- and D2-dopamine receptors, and dopamine and its metabolites in the human brain. Neuropsychopharmacology 11: 245-256.

Heinz A, Siessmeier T, Wrase J, Buchholz HG, Grunder G, Kumakura $\mathrm{Y}$ et al (2005). Correlation of alcohol craving with striatal dopamine synthesis capacity and D2/3 receptor availability: a combined [18 F]DOPA and [18 F]DMFP PET study in detoxified alcoholic patients. Am J Psychiatry 162: 1515-1520.

Hoffman JM, Melega WP, Hawk TC, Grafton SC, Luxen A, Mahoney DK et al (1992). The effects of carbidopa administration on 6-[18 F]fluoro-L-dopa kinetics in positron emission tomography. J Nucl Med 33: 1472-1477. 
Huttunen J, Heinimaa M, Svirskis T, Nyman M, Kajander J, Forsback $\mathrm{S}$ et al (2008). Striatal dopamine synthesis in first-degree relatives of patients with schizophrenia. Biol Psychiatry 63: 114-117.

Ingham CA, Hood SH, Arbuthnott GW (1989). Spine density on neostriatal neurones changes with 6-hydroxydopamine lesions and with age. Brain Res 503: 334-338.

Innis RB, Cunningham VJ, Delforge J, Fujita M, Gjedde A, Gunn $\mathrm{RN}$ et al (2007). Consensus nomenclature for in vivo imaging of reversibly binding radioligands. J Cereb Blood Flow Metab 27: 1533-1539.

Ito H, Kawaguchi H, Kodaka F, Takuwa H, Ikoma Y, Shimada H et al (2017). Normative data of dopaminergic neurotransmission functions in substantia nigra measured with MRI and PET: Neuromelanin, dopamine synthesis, dopamine transporters, and dopamine D2 receptors. NeuroImage 158: 12-17.

Ito $\mathrm{H}$, Kodaka F, Takahashi H, Takano H, Arakawa R, Shimada $\mathrm{H}$ et al (2011). Relation between presynaptic and postsynaptic dopaminergic functions measured by positron emission tomography: implication of dopaminergic tone. J Neurosci 31: 7886-7890.

Ito H, Ota M, Ikoma Y, Seki C, Yasuno F, Takano A et al (2006). Quantitative analysis of dopamine synthesis in human brain using positron emission tomography with L-[beta-11C]DOPA. Nucl Med Commun 27: 723-731.

Ito $\mathrm{H}$, Shidahara $\mathrm{M}$, Takano $\mathrm{H}$, Takahashi $\mathrm{H}$, Nozaki S, Suhara T (2007). Mapping of central dopamine synthesis in man, using positron emission tomography with L-[beta-11C]DOPA. Ann Nucl Med 21: 355-360.

Jonasson LS, Axelsson J, Riklund K, Braver TS, Ogren M, Backman $\mathrm{L}$ et al (2014). Dopamine release in nucleus accumbens during rewarded task switching measured by $[(1)(1) C]$ raclopride. NeuroImage 99: 357-364.

Jordan S, Eberling JL, Bankiewicz KS, Rosenberg D, Coxson PG, VanBrocklin HF et al (1997). 6-[18 F]fluoro-L-m-tyrosine: metabolism, positron emission tomography kinetics, and 1methyl-4-phenyl-1,2,3,6-tetrahydropyridine lesions in primates. Brain Res 750: 264-276.

Kienast T, Siessmeier T, Wrase J, Braus DF, Smolka MN, Buchholz HG et al (2008). Ratio of dopamine synthesis capacity to D2 receptor availability in ventral striatum correlates with central processing of affective stimuli. Eur J Nucl Med Mol Imaging 35: 1147-1158.

Klostermann EC, Braskie MN, Landau SM, O'Neil JP, Jagust WJ (2012). Dopamine and frontostriatal networks in cognitive aging. Neurobiol Aging 33: 623 e615-623 e624.

Kohler C, Fuxe K, Ross SB (1981). Regional in vivo binding of [3H] $\mathrm{N}$-propylnorapomorphine in the mouse brain. Evidence for labelling of central dopamine receptors. Eur J Pharmacol 72: 397-402.

Kohler C, Hall H, Ogren SO, Gawell L (1985). Specific in vitro and in vivo binding of $3 \mathrm{H}$-raclopride. A potent substituted benzamide drug with high affinity for dopamine D-2 receptors in the rat brain. Biochem Pharmacol 34: 2251-2259.

Kuczenski R, Segal D (1989). Concomitant characterization of behavioral and striatal neurotransmitter response to amphetamine using in vivo microdialysis. J Neurosci 9: 2051-2065.

Kuczenski R, Segal DS (1997). Effects of methylphenidate on extracellular dopamine, serotonin, and norepinephrine: comparison with amphetamine. J Neurochem 68: 2032-2037.

Kuwabara H, McCaul ME, Wand GS, Earley CJ, Allen RP, Weerts $\mathrm{EM}$ et al (2012). Dissociative changes in the Bmax and KD of dopamine D2/D3 receptors with aging observed in functional subdivisions of the striatum: a revisit with an improved data analysis method. J Nucl Med 53: 805-812.

Lammertsma AA, Hume SP (1996). Simplified reference tissue model for PET receptor studies. NeuroImage 4(3 Pt 1): 153-158.

Laruelle M, Abi-Dargham A, van Dyck CH, Gil R, D'Souza CD, Erdos J et al (1996). Single photon emission computerized tomography imaging of amphetamine-induced dopamine release in drug-free schizophrenic subjects. Proc Natl Acad Sci USA 93: 9235-9240.

Laruelle M, Abi-Dargham A, van Dyck CH, Rosenblatt W, ZeaPonce Y, Zoghbi SS et al (1995). SPECT imaging of striatal dopamine release after amphetamine challenge. J Nucl Med 36: 1182-1190.

Laruelle M, Iyer RN, al-Tikriti MS, Zea-Ponce Y, Malison R, Zoghbi SS et al (1997). Microdialysis and SPECT measurements of amphetamine-induced dopamine release in nonhuman primates. Synapse 25: 1-14.

Lee CS, Samii A, Sossi V, Ruth TJ, Schulzer M, Holden JE et al (2000). In vivo positron emission tomographic evidence for compensatory changes in presynaptic dopaminergic nerve terminals in Parkinson's disease. Ann Neurol 47: 493-503.

Levey AI, Hersch SM, Rye DB, Sunahara RK, Niznik HB, Kitt CA et al (1993). Localization of D1 and D2 dopamine receptors in brain with subtype-specific antibodies. Proc Natl Acad Sci USA 90: 8861-8865.

Martinez D, Carpenter KM, Liu F, Slifstein M, Broft A, Friedman AC et al (2011). Imaging dopamine transmission in cocaine dependence: link between neurochemistry and response to treatment. Am J Psychiatry 168: 634-641.

Martinez D, Saccone PA, Liu F, Slifstein M, Orlowska D, Grassetti A et al (2012). Deficits in dopamine $\mathrm{D}(2)$ receptors and presynaptic dopamine in heroin dependence: commonalities and differences with other types of addiction. Biol Psychiatry 71: 192-198.

Martinez D, Slifstein M, Broft A, Mawlawi O, Hwang DR, Huang Y et al (2003). Imaging human mesolimbic dopamine transmission with positron emission tomography. Part II: amphetamineinduced dopamine release in the functional subdivisions of the striatum. J Cereb Blood Flow Metab 23: 285-300.

Mawlawi O, Martinez D, Slifstein M, Broft A, Chatterjee R, Hwang $\mathrm{DR}$ et al (2001). Imaging human mesolimbic dopamine transmission with positron emission tomography: I. Accuracy and precision of $\mathrm{D}(2)$ receptor parameter measurements in ventral striatum. J Cereb Blood Flow Metab 21: 1034-1057.

McAllister AK (2000). Cellular and molecular mechanisms of dendrite growth. Cereb Cortex 10: 963-973.

Melega WP, Hoffman JM, Luxen A, Nissenson CH, Phelps ME, Barrio JR (1990). The effects of carbidopa on the metabolism of 6-[18 F] fluoro-L-dopa in rats, monkeys and humans. Life Sci 47: 149-157.

Monchi O, Ko JH, Strafella AP (2006). Striatal dopamine release during performance of executive functions: A [(11)C] raclopride PET study. NeuroImage 33: 907-912.

Nandhagopal R, Kuramoto L, Schulzer M, Mak E, Cragg J, Lee CS et al (2009). Longitudinal progression of sporadic Parkinson's disease: a multi-tracer positron emission tomography study. Brain 132(Pt 11): 2970-2979.

Nandhagopal R, Kuramoto L, Schulzer M, Mak E, Cragg J, McKenzie J et al (2011). Longitudinal evolution of compensatory changes in striatal dopamine processing in Parkinson's disease. Brain 134(Pt 11): 3290-3298.

Narendran R, Jedema HP, Lopresti BJ, Mason NS, Gurnsey K, Ruszkiewicz J et al (2014). Imaging dopamine transmission in the frontal cortex: a simultaneous microdialysis and [11C]FLB 457 PET study. Mol Psychiatry 19: 302-310.

Okada M, Nakao R, Hosoi R, Zhang MR, Fukumura T, Suzuki K et al (2011). Microdialysis with radiometric monitoring of L-[beta-11C]DOPA to assess dopaminergic metabolism: effect of inhibitors of L-amino acid decarboxylase, monoamine oxidase, and catechol-O-methyltransferase on rat striatal dialysate. J Cereb Blood Flow Metab 31: 124-131.

Patlak CS, Blasberg RG (1985). Graphical evaluation of blood-tobrain transfer constants from multiple-time uptake data. Generalizations. J Cereb Blood Flow Metab 5: 584-590.

Poletti CE, Creswell G (1977). Fornix system efferent projections in the squirrel monkey: an experimental degeneration study. J Comp Neurol 175: 101-128. 
Robinson TE, Gorny G, Mitton E, Kolb B (2001). Cocaine selfadministration alters the morphology of dendrites and dendritic spines in the nucleus accumbens and neocortex. Synapse 39: 257-266.

Robinson TE, Kolb B (1997). Persistent structural modifications in nucleus accumbens and prefrontal cortex neurons produced by previous experience with amphetamine. J Neurosci 17: 8491-8497.

Ross SB, Jackson DM (1989a). Kinetic properties of the in vivo accumulation of $3 \mathrm{H}-(-)-\mathrm{N}$-n-propylnorapomorphine in mouse brain. Naunyn Schmiedebergs Arch Pharmacol 340: 13-20.

Ross SB, Jackson DM, Edwards SR (1989b). The involvement of dopamine D1 and D2 receptors in the locomotor stimulation produced by $(+)$-amphetamine in naive and dopaminedepleted mice. Pharmacol Toxicol 64: 72-77.

Rousset OG, Ma Y, Evans AC (1998). Correction for partial volume effects in PET: principle and validation. J Nucl Med 39: 904-911.

Russchen FT, Bakst I, Amaral DG, Price JL (1985). The amygdalostriatal projections in the monkey. An anterograde tracing study. Brain Res 329: 241-257.

Salinas CA, Searle GE, Gunn RN (2015). The simplified reference tissue model: model assumption violations and their impact on binding potential. J Cereb Blood Flow Metab 35: 304-311.

Seeman P, Guan HC, Niznik HB (1989). Endogenous dopamine lowers the dopamine $\mathrm{D} 2$ receptor density as measured by [3H] raclopride: implications for positron emission tomography of the human brain. Synapse 3: 96-97.

Sharp T, Zetterstrom T, Ljungberg T, Ungerstedt U (1987). A direct comparison of amphetamine-induced behaviours and regional brain dopamine release in the rat using intracerebral dialysis. Brain Res 401: 322-330.

Slifstein M, Laruelle M (2001). Models and methods for derivation of in vivo neuroreceptor parameters with PET and SPECT reversible radiotracers. Nucl Med Biol 28: 595-608.

Smith CT, Wallace DL, Dang LC, Aarts E, Jagust WJ, D'Esposito M et al (2016). Modulation of impulsivity and reward sensitivity in intertemporal choice by striatal and midbrain dopamine synthesis in healthy adults. J of neurophysiology 115: 1146-1156.

Sossi V, de La Fuente-Fernandez R, Holden JE, Doudet DJ, McKenzie J, Stoessl AJ et al (2002). Increase in dopamine turnover occurs early in Parkinson's disease: evidence from a new modeling approach to PET 18 F-fluorodopa data. J Cereb Blood Flow Metab 22: 232-239.

Sossi V, Holden JE, de la Fuente-Fernandez R, Ruth TJ, Stoessl AJ (2003). Effect of dopamine loss and the metabolite 3-O-methyl[18 F]fluoro-dopa on the relation between the $18 \mathrm{~F}$-fluorodopa tissue input uptake rate constant Kocc and the [18 F]fluorodopa plasma input uptake rate constant Ki. J Cereb Blood Flow Metab 23: 301-309.

Tsukada H, Nishiyama S, Kakiuchi T, Ohba H, Sato K, Harada N (1999). Is synaptic dopamine concentration the exclusive factor which alters the in vivo binding of [11C]raclopride?: PET studies combined with microdialysis in conscious monkeys. Brain Res 841: $160-169$

Van Hoesen GW, Yeterian EH, Lavizzo-Mourey R (1981). Widespread corticostriate projections from temporal cortex of the rhesus monkey. J Comp Neurol 199: 205-219.

VanBrocklin HF, Blagoev M, Hoepping A, O'Neil JP, Klose M, Schubiger PA et al (2004). A new precursor for the preparation of 6-[18 F]Fluoro-L-m-tyrosine ([18 F]FMT): efficient synthesis and comparison of radiolabeling. Appl Radiat Isotopes 61: 1289-1294.

Volkow ND, Fowler JS, Wang GJ, Dewey SL, Schlyer D, MacGregor $\mathrm{R}$ et al (1993). Reproducibility of repeated measures of carbon-11raclopride binding in the human brain. J Nucl Med 34: 609-613.

Volkow ND, Gur RC, Wang GJ, Fowler JS, Moberg PJ, Ding YS et al (1998a). Association between decline in brain dopamine activity with age and cognitive and motor impairment in healthy individuals. Am J Psychiatry 155: 344-349.

Volkow ND, Wang G, Fowler JS, Logan J, Gerasimov M, Maynard L et al (2001). Therapeutic doses of oral methylphenidate significantly increase extracellular dopamine in the human brain. J Neurosci 21: RC121.

Volkow ND, Wang GJ, Fowler JS, Gatley SJ, Logan J, Ding YS et al (1998b). Dopamine transporter occupancies in the human brain induced by therapeutic doses of oral methylphenidate. Am J Psychiatry 155: 1325-1331.

Volkow ND, Wang GJ, Fowler JS, Logan J, Franceschi D, Maynard $\mathrm{L}$ et al (2002). Relationship between blockade of dopamine transporters by oral methylphenidate and the increases in extracellular dopamine: therapeutic implications. Synapse 43: $181-187$.

Volkow ND, Wang GJ, Fowler JS, Logan J, Gatley SJ, MacGregor RR et al (1996). Measuring age-related changes in dopamine D2 receptors with 11C-raclopride and $18 \mathrm{~F}-\mathrm{N}$-methylspiroperidol. Psychiatry Res 67: 11-16.

Volkow ND, Wang GJ, Fowler JS, Logan J, Gatley SJ, Wong C et al (1999). Reinforcing effects of psychostimulants in humans are associated with increases in brain dopamine and occupancy of D (2) receptors. J Pharmacol Exp Ther 291: 409-415.

Volkow ND, Wang GJ, Telang F, Fowler JS, Alexoff D, Logan J et al (2014). Decreased dopamine brain reactivity in marijuana abusers is associated with negative emotionality and addiction severity. Proc Natl Acad Sci USA 111: E3149-E3156.

Wallace DL, Aarts E, Dang LC, Greer SM, Jagust WJ, D'Esposito M (2014). Dorsal striatal dopamine, food preference and health perception in humans. PLoS One 9: e96319.

Wang HD, Deutch AY (2008). Dopamine depletion of the prefrontal cortex induces dendritic spine loss: reversal by atypical antipsychotic drug treatment. Neuropsychopharmacology 33: 1276-1286.

Whitford KL, Dijkhuizen P, Polleux F, Ghosh A (2002). Molecular control of cortical dendrite development. Annu Rev Neurosci 25: 127-149.

Yeterian EH, Van Hoesen GW (1978). Cortico-striate projections in the rhesus monkey: the organization of certain cortico-caudate connections. Brain Res 139: 43-63.

Young LT, Wong DF, Goldman S, Minkin E, Chen C, Matsumura K et al (1991). Effects of endogenous dopamine on kinetics of [3H] $\mathrm{N}$-methylspiperone and $[3 \mathrm{H}]$ raclopride binding in the rat brain. Synapse 9: 188-194.

Zaja-Milatovic S, Milatovic D, Schantz AM, Zhang J, Montine KS, Samii A et al (2005). Dendritic degeneration in neostriatal medium spiny neurons in Parkinson disease. Neurology 64: 545-547.

Zhu MY, Juorio AV, Paterson IA, Boulton AA (1992). Regulation of aromatic L-amino acid decarboxylase by dopamine receptors in the rat brain. $J$ Neurochem 58: 636-641.

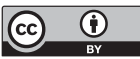

This work is licensed under a Creative Commons Attribution 4.0 International License. The images or other third party material in this article are included in the article's Creative Commons license, unless indicated otherwise in the credit line; if the material is not included under the Creative Commons license, users will need to obtain permission from the license holder to reproduce the material. To view a copy of this license, visit http://creativecommons.org/licenses/ by/4.0/

(C) The Author(s) 2018

Supplementary Information accompanies the paper on the Neuropsychopharmacology website (http://www.nature.com/npp) 